5 Research Square
Preprints are preliminary reports that have not undergone peer review.

They should not be considered conclusive, used to inform clinical practice, or referenced by the media as validated information.

\title{
Arsenic in Mining Area: Environmental Contamination Route
}

\section{Rodrigo Hott}

UFVJM: Universidade Federal dos Vales do Jequitinhonha e Mucuri

\section{Grazielle Oliveira}

UFVJM: Universidade Federal dos Vales do Jequitinhonha e Mucuri

\section{Cleide Bomfeti}

UFVJM: Universidade Federal dos Vales do Jequitinhonha e Mucuri

\section{Maicon Sousa}

UFVJM: Universidade Federal dos Vales do Jequitinhonha e Mucuri

\section{Mayra Santos}

UFVJM: Universidade Federal dos Vales do Jequitinhonha e Mucuri

\section{Thainá Andrade}

UFVJM: Universidade Federal dos Vales do Jequitinhonha e Mucuri

\section{Márcia Faria}

UFVJM: Universidade Federal dos Vales do Jequitinhonha e Mucuri

\section{Fernando Barbosa}

USP: Universidade de Sao Paulo

Jairo Lisboa Rodrigues ( $\nabla$ jairo.rodrigues@ufvjm.edu.br)

Universidade Federal dos Vales do Jequitinhonha e Mucuri https://orcid.org/0000-0001-6088-5232

\section{Research Article}

Keywords: arsenic, mining, contamination, genotoxic, metals, particulate matter

Posted Date: May 5th, 2021

DOI: https://doi.org/10.21203/rs.3.rs-481921/v1

License: (c) (1) This work is licensed under a Creative Commons Attribution 4.0 International License.

Read Full License 


\section{Abstract}

The emission of residues has contributed immensely to the fact that man is susceptible and exposed to toxic chemical products, among them, arsenic. One of the main anthropic sources of arsenic in the world is mining, which can contribute to the contamination of soil, water, air, and food. An example of environmental arsenic contamination in Brazil occurs in the city of Paracatu - MG, due to the operation of a gold mine. Thus, the objectives of this study were: (i) to assess the physical-chemical parameters and the concentration of arsenic in samples of superficial fresh water (sub-basin of the Paracatu River), and soil samples, during winter and summer; (ii) evaluate the arsenic concentration in samples of particulate matter; (iii) determine the concentration and species of As in biological samples and (iiii) evaluate the toxicity of surface waters using the Allium cepa test. There was no change in the physical-chemical parameters. The water samples collected during the winter and all soil samples showed values of As above those allowed by organs regulatory agencies. The values of As in the particulate material showed great variations between the regions under study but were within the limit established by the ATSDR for urban areas. Inorganic and organic As was found above the limit allowed in biological samples The analysis of water toxicity by the Allium cepa test indicated the presence of cytotoxic and genotoxic compounds, demonstrating a great risk for the population exposed to the waters of the Rico stream.

\section{Introduction}

Arsenic (As) is a grayish-colored crystalline metalloid, with an atomic number 33 and an atomic mass of $74.9 \mathrm{~g} \cdot \mathrm{mol}^{-1}$ (Yin et al. 2017). It is listed by the Agency for Toxic Substances and Disease Registry (ATSDR) from the Department of Health of the United States, first among substances toxic to human health, being recognized as an important carcinogen (ATSDR 2019; Wang et al. 2020).

This element is widely distributed in the biosphere and can be found in the atmosphere, in water, in soils, and in organisms. Despite being considered a trace element, its concentration in the environment has become increasingly greater due to natural phenomena such as weathering and volcanic eruptions and anthropogenic actions, such as the release of domestic and industrial effluents, pesticides, and mainly by mining activity (Dos Santos Farias et al. 2012). In the environment, the toxicity of the metal depends on the oxidation state and the chemical structure of the metallic species. Arsenic exists in nature in a variety of chemical forms, including organic species such as monomethylarsonic acid (MMA), dimethylarsinic acid (DMA), arsenobetaine (AsB), and arsenocholine (AsC); and inorganic, the most toxic and formed by arsenate $\left(\mathrm{As}^{+5}\right)$ and arsenite $\left(\mathrm{As}^{+3}\right)$ It is worth mentioning that the inorganic compounds of As are about 100 times more toxic than the partially methylated organic forms (MMA and DMA, since the increasing order of toxicity of the As compounds, are: organic compounds of $\mathrm{As}^{5+}<$ compounds organic of $\mathrm{As}^{3+}<$ compounds inorganic of $\mathrm{As}^{5+}<$ compounds inorganic of $\mathrm{As}^{3+}$ (Borba et al. 2009). A caveat must be made regarding DNA damage, where the trivalent methylated arsenic species, that is, MMA (III) and DMA (III), were considered more toxic than inorganic arsenic because they are more efficient in causing the breaking of DNA (Styblo et al. 2000). 
Most of the As in the environment is associated with rocks and minerals. It is present in more than 200 minerals. The majority as arsenate and arsenic sulfides, and to a less quantity as arsenites, oxides, and elemental As (Rezende et al. 2015). As has a high affinity with some elements like sulfur and iron, making the presence of sulfate minerals, for example, generate low mobility to other environmental compartments (Mandal and Suzuki 2002). Arsenopyrite is the most common sulfide mineral, which is generally associated with gold ( $\mathrm{Au}$ ) mining. Its oxidation, dependent on several factors, including the amounts of arsenopyrite, distribution of the size of the ore, temperature, and the time of exposure of the material to water and oxygen (De Andrade et al. 2008), produces arsenic oxyacids that facilitate their release into the soil and watercourse (De Andrade et al. 2012).

Its excretion occurs through metabolism in the liver, where the $\mathrm{As}^{+5}$ is reduced by the enzyme arsenate reductase to $\mathrm{As}^{+3}$, which is methylated to methyl arsonate $\left(\mathrm{MMA}^{+5}\right)$ and, sequentially, to dimethyl arsenic acid $\left(\mathrm{DMA}^{+5}\right)$ by As-methyl transferase enzyme. This conversion from As-i to As-o allows its excretion in the urine (Thompson 1993; Klaassen 2013). The amount of $\mathrm{As}^{+3}, \mathrm{As}^{+5}, \mathrm{MMA}$, and DMA in the urine may vary according to exposure conditions, route of administration, and dose. This urinary excretion ends up being part of the domestic sewage, being one more factor of increasing As in rivers and streams that receive domestic effluents without treatment (Jasrotia et al. 2013).

Mining activities are the main anthropic sources of As release to the environment. Gold mine tailings and effluents generally contain high concentrations of arsenic and are a cause for concern as potential sources of environmental contamination (Jang et al. 2016). In addition to solid and liquid tailings, mining is also responsible for releasing As into the atmosphere, along with particulate matter that is suspended in the air during processing in gold mines. The As is removed from the atmosphere by dry deposition or rain. Some airborne particles can condense into dust particles that can be inhaled or ingested $(\mathrm{Ng}$ et al. 2019).

The impact on humans of particulate material (PM) containing As is mainly related to health and generally associated with the inhalation of particles less than $10 \mu \mathrm{m}$ in diameter. Breathable particles ( $<2.5 \mu \mathrm{m}$ in diameter) can reach the pulmonary alveoli (Brewer and Belzer 2001). Although there is no national legislation that determines the amount for As in the air, the ATSDR (ATSDR 2019), establishes values from 20 to $100 \mathrm{ng} . \mathrm{m}^{3}$ in remote and urban areas respectively. Values below the recommended by ATSDR, when chronically inhaled and associated with other sources of As contamination, such as water and food, have already been related to the increased incidence of cancer (Yoshikawa et al. 2008).

One way to assess the impact of environmental contamination by As is through the analysis of animal and plant species that are exposed to this metal. As has a great capacity to generate biomagnification at different trophic levels of the food chain and its presence in the environment is quickly detected in organisms exposed to that environment, being a strong indicator of risk to humans (Hettick et al. 2015). In addition to detecting the presence of As, it is also essential, from the point of view of food security, to determine the species and their quantities in the food consumed by humans, allowing a more accurate 
assessment of health risk, as different species of As exhibit different properties physical-chemical and toxicities (Barra et al. 2000; Styblo et al. 2000).

Epidemiological studies point to the high carcinogenic potential and mutagenic risk of As for humans. Individuals with elevated cytogenetic changes are at increased risk of developing cancer (Souza et al. 2015). Therefore, tests with living organisms or bioassays are important to predict possible human and environmental health risks. The Allium cepa test is considered an efficient bioindicator of substances with potential, genotoxic, and mutagenic, evaluating chromosomal changes and aberrations generated by contaminants in meristematic cells through cytotoxicity, genotoxicity, and mutagenicity studies. It is a low-cost and easy-to-use test; the rapid root growth with a reduced number of chromosomes presenting a considerable size facilitates its visualization and analysis (Leme and Marin-Morales 2009).

Gold mining is one of the main factors responsible for the increase of As in many ecosystems on the planet, through effluents, soil leaching, and dust particles released during the mining process, affecting plants, animals, and humans. As a result, populations, especially those close to industrial and geological sources, are exposed to higher levels of As in various ways, such as food, drinking water, soil, and ambient air (Wang and Mulligan 2006), causing serious health impacts.

The occurrence, distribution, origin, and mobility of As have received significant attention in recent years. The knowledge of the processes that govern the accumulation of As in the environment, as well as the possible toxic effects caused to the population of the affected areas is necessary to obtain a better understanding. This study was carried out in the city of Paracatu-MG, known for gold mining, which has existed since the 18th century, occurring mainly near the Rico stream, an important tributary of the Paracatu River basin and whose source is located in a mining area of gold, cutting the entire urban area along its path (Rezende et al. 2015). The objective of this study was to carry out an assessment of environmental contamination by As in the municipality of Paracatu-MG, by analyzing the soil, the surface waters of the Rico stream, and the particles present in the atmosphere, verifying the trophic transfer of As to fish and species present in this environment, as a way of determining the potential risk for human contamination in this region. The toxic effects of surface waters were also evaluated through studies of cytotoxicity, genotoxicity, and mutagenixity, expanding our knowledge of global As problems.

\section{Materials And Methods}

\subsection{Materials and chemicals}

All reagents used in the experiments were of analytical grade and used without further purification. The reagents used were weighed on a Shimadzu analytical scale, model AUY220 to prepare the solutions. The solutions were prepared using ultrapure water (resistivity $18.0 \mathrm{M} \Omega \mathrm{cm}$ ) obtained by the Thermo Scientific Barnstead $^{\text {TM }}$ Nanopure ${ }^{\text {TM }}$ system. 
The reagents $\mathrm{Na}_{2} \mathrm{HAsO}_{4} \cdot 7 \mathrm{H}_{2} \mathrm{O}$ (CAS: 10048-95-0), $\mathrm{NaAsO}_{2}$ (CAS: 7784-46-5), Schiff reagent (CAS: 373994-4), Triton X-100 (CAS: 9036-19-5) and $\mathrm{CuSO}_{4}$ (CAS: 7758-98-7) were provided by Sigma-Aldrich. And the reagents $\mathrm{NaOH}$ (CAS: 1310-73-2), $\mathrm{HNO}_{3}$ (CAS: 7697-37-2), $\mathrm{CH} 囚 \mathrm{COOH}$ (CAS: 64-19-7), and $\mathrm{HCl}$ (CAS: 7647-01-0) were purchased from Vetec (Brazil). Rhodium (Ra) (CAS: 7440-14-4) and multi-elementary solution were obtained from PerkinElmer. $\mathrm{C}_{2} \mathrm{H}_{5} \mathrm{OH}$ (CAS: 64-17-5) obtained from Cosmoquímica. Allium cepa $L$ was obtained commercially from Teofilo Otoni (Brazil).

\subsection{Study location and collection points}

The study was carried out in Paracatu, a city in the State of Minas Gerais, with approximately 85,000 inhabitants, where the largest open-pit gold mine in Brazil, "Morro do Ouro". It is located, $2 \mathrm{~km}$ from the urban center of the municipality (Mertens et al. 2017), at latitude $17^{\circ} 13^{\prime} 21^{\prime \prime} \mathrm{S}$ and longitude $46^{\circ} 52^{\prime} 31^{\prime \prime}$ W, near the Rico stream. This mine is located in the sub-basin of the Paracatu River, which belongs to the São Francisco River Basin (Rezende et al. 2015).

Environmental samples, such as water from the Rico stream, soil of its banks, and particulate matter from the atmosphere, as well as biological samples such as fish and plants were collected to assess levels of contamination by As. Physical-chemical parameters were also determined: $\mathrm{pH}$, turbidity, and concentrations of $\mathrm{Mg}^{2+}$ and $\mathrm{Ca}^{2+}$ ions. Cytotoxicity, genotoxicity, and mutagenicity were evaluated in water samples by the Allium cepa bioassay.

Sample collection took place during the winter of 2017 (dry season) and summer of 2018 (rainy season). Three collections of water and soil were made at five different points along the Rico stream (Fig. 1). The first point is close to the source, within the mining area, three points in the urban region, and the last point after the urban area. Sample collections were performed according to the procedure adopted by the Environmental Company of the State of São Paulo (CETESB 2011).

$1000 \mathrm{~mL}$ of water were collected, in triplicate, in polypropylene metal-free flasks. The soil samples were collected in triplicate using a $20 \mathrm{~cm}$ drill, in a polypropylene container, containing $500 \mathrm{~g}$ of sample. The particulate material (PM) samples were taken in two regions of the city known as "Amoreiras" and "Chapadinha". The Amoreiras region is close to the mining region while the Chapadinha region is located at the southern end of the city, farther from the mining region (Fig. 1). Samples of corn, cassava, and fish were collected in the Rico stream area during the winter of 2017. The samples were stored in metal-free plastic bags and packed in refrigerated coolers for less than 24 hours.

\subsection{Analysis of arsenic from environmental samples}

\subsubsection{Quantification of arsenic in the samples}


All experiments were performed in triplicate in a clean room (class 1000). Calibration curves in the range of 1 and $50 \mu \mathrm{g} . \mathrm{L}^{-1}$ (As) were prepared up with analytical standards, and the limit of detection found was $0.009 \mu \mathrm{g} \cdot \mathrm{L}^{-1}$. All samples analyzed were diluted in $2 \%(\mathrm{v} / \mathrm{v})$ nitric acid solution $\left(\mathrm{HNO}_{3}\right)$ using the protocol established by EPA 200.8 (Pruszkowski and Bosnak 2007).

The concentrations of arsenic were determined with an Inductively Coupled Plasma Mass Spectrometry (ICP-MS) NexION 300D da PerkinElmer (EUA) with a Meinhard nebulizer and quartz cyclonic spray chamber and continuous nebulization. The operating conditions were: Nebulizer Gas flow rates: $0.95 \mathrm{~L}$ $\mathrm{min}^{-1}$; Auxiliary Gas Flow: 1.2 L min-1; Plasma Gas Flow: $15 \mathrm{~L} \mathrm{~min}^{-1}$; Lens Voltage: $7.25 \mathrm{~V}$; ICP RF Power: $1300 \mathrm{~W} ; \mathrm{CeO} / \mathrm{Ce}=0.011 ; \mathrm{Ba}^{++} / \mathrm{Ba}^{+}=0.016$.

\subsubsection{Soil samples}

The soil samples were dried at $60^{\circ} \mathrm{C}$ for 48 hours and sieved $(20 \mu \mathrm{m})$. Afterward, $1.0 \mathrm{~g}$ was subjected to acid extraction with $10 \mathrm{~mL}$ of distilled $\mathrm{HNO}_{3}$, assisted by a CEM microwave digester, model MARS 6, according to method 3051A of the United States Environmental Protection Agency (USEPA 2007). After digestion, the aliquots of the solution were analyzed by ICP-MS. The data were analyzed by ANOVA variance with $95 \%$ confidence interval and Tukey test with significance level $a=0.05$.

\subsubsection{Water samples}

Aliquots of the water samples were diluted in $2 \% \mathrm{HNO}_{3}$ solution and analyzed by Method $3051 \mathrm{a}$, from the United States Environmental Protection Agency (USEPA 2007). After dilution, aliquots of the solutions were analyzed by ICP-MS. The data were analyzed by ANOVA, variance with a $95 \%$ confidence interval and Tukey test with significance level $a=0.05$.

\subsubsection{Particulate material samples}

Particulate matter up to $2.5 \mu \mathrm{m}$ (PM 2.5) and total suspended particulate matter (PTS) were collected by Pall Life Sciences glass fiber membrane filters with 24-hour cycles, using a large volume sampler for determination of the concentration of respirable particles (up to $2.5 \mu \mathrm{m}$ ) in ambient air (AGV MP2.5), with separation head and volumetric flow controller (CVV), and a large volume sampler (AGV) for the determination the concentration of PTS in ambient air, both manufactured by Energica. The sampling method was carried out by the rules for sample collection (EPA 2006) and in accordance with the National Environment Council (CONAMA) (Siciliano et al. 2020).

To determine the As levels in the PM present in the filters, the adapted Method IO-3.1 from the American Environmental Protection Agency was used (US EPA) (States and Protection 1999). The filters were dried (24 hours) and weighed, before and after PM collection. The weight difference corresponded to the total mass collected. Then, the particles were subjected to acid extraction with $10 \mathrm{~mL}$ of distilled HNO3, assisted by a CEM microwave digester, model MARS 6, according to US EPA method 3051A (USEPA 
2007). After digestion, the aliquots of the solution were analyzed by ICP-MS. The data were analyzed by ANOVA variance with $95 \%$ confidence interval and Tukey test with significance level $a=0.05$.

\subsection{Determination of hydrogen potential $(\mathrm{pH})$, water hardness, and turbidity}

In the water samples collected in the Rico stream, determinations of hydrogen potential and calcium carbonate concentration (hardness) were performed to assess the retention and/or release of metals from sediments into the water (APHA, AWWA 2012).

For the determination of the $\mathrm{pH}$, a $\mathrm{pH}$ meter manufactured by Digimed, model $\mathrm{DM}-2 \mathrm{P}$, was used. The determination of water hardness was carried out using the Aquamerk determination kit (Merk $\left.{ }^{\circledR}\right)$. To determine the turbidity of the water samples, a Hanna instruments turbidimeter, model HI93703C, was used.

\subsection{Quantification of As species in maize, cassava and fish}

Corn, a cereal, and cassava, a tuberous root, are foods widely grown and consumed in Brazil. Due to the great absorption of As, they can be a vehicle of this metal in the food chain, generating bioaccumulation and serving as a good bioindicator of environmental contamination. Another important indicator, used to measure the contamination of As in aquatic ecosystems are fish, which can accumulate this metal through water, food, and sediments, occurring biomagnification of metals (Rocha et al. 2015). In this work, we used samples of the axial muscle of the fish Traíra (Hoplias malabaricus) and Dourado (Salminus maxillosus), the grains of corn (Zea mays L.) and the tuberous part of the cassava (Manihot esculenta), without the husk.

Briefly, the corn, cassava, and fish muscle samples were washed, crushed, lyophilized, and sieved. After this preparation, $100 \mathrm{mg}$ of each sample was weighed in triplicate so that they could be pre-digested (48 h) using $2.0 \mathrm{~mL}$ of sub-distilled $\mathrm{HNO}_{3}$. Then, the samples were heated $\left(90^{\circ} \mathrm{C}\right)$ for 4 hours in a microwave oven (model MARS 6), and the volume was made up to $50 \mathrm{~mL}$ with ultrapure water (Batista et al. 2010). After digestion, the samples were cooled to room temperature, filtered with a $0.20 \mu \mathrm{m}$ cellulose filter, and injected directly into the LC-ICP-MS. The samples were loaded with a syringe into a $100 \mu \mathrm{L}$ sample loop. All chromatographic separations were performed with a PRP-X100 anion exchange column $(150 \mathrm{~mm} \mathrm{X}$ $4.6 \mathrm{~mm}, 5 \mu \mathrm{m}$ ) (Hamilton, Reno, NV, USA) at $25^{\circ} \mathrm{C}$ under isocratic conditions. The mobile phase, with a flow rate of $1 \mathrm{~mL} \mathrm{~min}{ }^{-1}$, composed of $10 \mathrm{mmol} \mathrm{L}^{-1} \mathrm{HPO}_{4}{ }^{2-} / \mathrm{H}_{2} \mathrm{PO}_{4}{ }^{-}(\mathrm{pH}$ 8.5) $(98 \%(\mathrm{v} / \mathrm{v})$ ) and methanol $(2 \%(\mathrm{v} / \mathrm{v}))$. Analytical calibration standards for As species $\left(\mathrm{As}^{3+}, \mathrm{As}^{5+}, \mathrm{DMA}\right.$, and MMA) were prepared in the range of $1.0-20.0 \mu \mathrm{g} \mathrm{L}^{-1}$ by serial dilutions. The data were analyzed by ANOVA, variance with a $95 \%$ confidence interval and Tukey test with significance level $a=0.05$.

\subsection{Allium cepa test}


The Allium cepa test is an important bioassay to monitor the potential synergistic effects of a mixture of pollutants, including toxic metals (FISKESJÖ 1985; Leme and Marin-Morales 2009), allowing the determination of the cytotoxicity, genotoxicity, and mutagenicity of As present in water (Hott et al. 2020) (HOTT, 2020). The present study was carried out according to methods described in previous studies with modification (Grant 1982; Blanc et al. 2013; Mourão et al. 2019).

To perform the test, 100 seeds of Allium cepa were used for each water sample from the Rico stream, spread over a Petri dish containing filter paper moistened with $6 \mathrm{~mL}$ of sample. As a negative control, ultrapure water $(18 \mathrm{M} \Omega \mathrm{cm})$ was used and as a positive control CuSO4 (0.006 mg.mL-1). The experiment was maintained in a germination chamber (Thermo Scientific, USA) at $25^{\circ} \mathrm{C}$ under constant light for five days. After this period, the growing roots were measured with the aid of a caliper ruler.

The rate of root inhibition was assessed by the average length of growing seeds (ALS) (Blanc et al. 2013). To obtain the ALS, arithmetic mean was performed, according to the root sizes. To determine the inhibition index, equation 1 was applied:

\section{Inhibition rate $=($ Negative control ALS $)-($ ALS at the analyzed point $) * 100(1)$}

To determine the mitotic index, genotoxicity, and mutagenicity of samples from the Rico stream, the roots were cut and fixed with Carnoy solution for 6 hours and later replaced by $1 \mathrm{~mL}$ of $70 \%$ ethanol for 6 more hours. After this period, the roots were washed with ultrapure water and then subjected to hydrolysis with a $1 \mathrm{M} \mathrm{HCl}$ solution in a water bath at $60^{\circ} \mathrm{C}$ for 9 min and stained with Schiff's reagent for 2 hours in the dark. Then, the root was cut, placed on a slide, and then a drop of $2 \%$ acetic carmine solution was added. After $8 \mathrm{~min}$, it was covered with coverslips and carefully kneaded. To determine the IM, equation 2 was used:

\section{$\mathrm{MI}=\mathrm{MCN} / \mathrm{TCN} * 100(2)$}

where MCN corresponds to the number of mitotic cells and CTN means the total number of cells analyzed. All cells in mitosis were quantified and analyzed. Chromosomal aberrations caused by changes in structure or the total number of chromosomes have been identified to determine genotoxicity. The increase in the number of micronuclei was used to determine the occurrence of mutagenicity.

\section{Results And Discussion}

\subsection{Physico-chemical parameters and arsenic concentration in surface water and soil on the banks of the Rico stream}

The results of the physical-chemical parameters of the surface waters of the Rico stream, in the municipality of Paracatu, are listed in Table 1.

The samples collected in the five points of the Rico stream in the dry and rainy season have $\mathrm{pH}$ values close to neutrality, ranging from 6.0 to 7.1 and, therefore, in accordance with Brazilian legislation 
(Conama 2005).

Hardness represents the measure of the water's ability to precipitate soap due to the presence of calcium and magnesium ions (Rizzatti et al. 2018), being, therefore, calculated from the concentration of these ions (Libânio et al. 2006). Samples P1 and P2, collected in the rainy season, were classified as moderately hard, due to the presence of a large amount of $\mathrm{Ca}^{2+}$ and $\mathrm{Mg}^{2+}$ in the water close to the spring, accentuated by the weathering in the rainy season. Following the course of the stream, as it enters the city, a drop in hardness occurs due to the natural sedimentation of $\mathrm{Ca}^{2+}$ and $\mathrm{Mg}^{2+}$. This hardness increases again after leaving the city due to the deposition of untreated domestic sewage, becoming more evident in P5, collected in the dry period, where there is a lower volume of water and the same volume of sewage. Concerning turbidity, a property that assesses the difficulty of water transmitting light due to the presence of suspended materials such as clay, organic matter, plankton, and other microscopic organisms. The main sources of suspended materials are particles originating from weathering processes that occur in rocks and soils in the hydrographic basin, being directly related to mining activities, deforestation, and discharge of domestic effluents (Parron et al. 2011). The waters of the studied region showed turbidity ranging from 0.71 to $8.3 \mathrm{UNT}$, with no major differences between samples collected in the dry season and rainy season. The turbidity values proved to be low, being within the requirements of the legislation.

To analyze the values of As in the surface waters of the Rico stream, we consider the CONAMA 357 resolution (Conama 2005) and the World Health Organization (WHO 2011), which classifies the studied stream waters as class 2 , and determines that the maximum concentration of $A s$ is $10 \mu \mathrm{g} . \mathrm{L}^{-1}$, so that it can be used for human supply (after conventional treatment), primary contact recreation, protection of aquatic communities, irrigation, aquaculture, and fishing activities.

We found (Fig. 2A) that the only surface water sample collected in the summer (rainy season) that showed a high concentration of As, was point 5 , with a value $300 \%$ above the limit. As for the samples collected in the winter (dry season), all five points showed increased values for As, which represents a matter of concern regarding the consumption and use of water for irrigation. It is important to mention that collection site 1 is the closest to the mining area. On the other hand, the high values of As found in the water of site 5 , both in the dry and in the rainy season, can be explained by the natural presence of As in the soils of the studied region and by the residential sewage discharged into the stream.

We observed a seasonal behavior since all samples collected during the summer showed low levels about the winter. Although regional rains during this time of year cause leaching of arsenic-rich soils (Silva et al. 2004), it also ends up diluting the arsenic naturally found in these waters, due to the increased volume of water in rivers and streams. We also have to consider that the mineral form of arsenopyrite, very common in the mining region of Paracatu, can be oxidized, releasing As to the soil and watercourse, due to the influence of some factors such as particle size distribution, low pH values, heat and exposure to water and oxygen (De Andrade et al. 2012). These factors are less influential in the rainy season, due to the increase in rainwater. 
The average annual humidity in the city of Paracatu is around $72 \%$, with the months from June to August being the driest and the months from December to January are the most humid. The monthly average of the rainfall index between the years 1973 to 2018 can be seen in Fig.3.

The concentrations of As in soils are above that established by CONAMA resolution number 420 of 2009, which establishes an acceptable value to be below $15 \mathrm{mg} \mathrm{kg}^{-1}$, being considered intervention values in agricultural, residential, and industrial regions above 35,55 , and $150 \mathrm{mg}^{-\mathrm{kg}^{-1}}$, respectively (CONAMA 2009).

According to the results of the analysis of As, in the soil, along the Rico stream, (Fig. 2B) all the sampled points are well above the minimum required by the legislation, with values exceeding more than one hundred times the established limit. The highest values were found in the locations closest to the gold mine, with values collected during the rainy season of 1.502 and $1.545 \mathrm{mg} \mathrm{kg}^{-1}$, in points 1 and 2 respectively. For the dry season, the concentration found was $1.668 \mathrm{mg} \mathrm{kg}^{-1}$ at point 1 and $1.257 \mathrm{mg}_{\mathrm{kg}}{ }^{-1}$ at point 2 . The values found are by what was reported by Rezende et al. 2015, which detected concentrations of arsenic in soils in the city of Paracatu ranging from 32 to $2.980 \mathrm{mg} \cdot \mathrm{kg}^{-1}$.

The Rico stream can present concentrations 190 times higher than that stipulated by environmental legislation and 744 times higher than the average natural concentration of rivers and streams in the region, with high levels of As associated with the natural sources of the Paracatu region and the exploration of gold (Rezende et al. 2015). According to the Minas Gerais Water Management Institute (IGAM 2019) concentrations of As above the level considered safe by CONAMA (CONAMA 2004), can cause several adverse effects to the biological community. According to CETESB (CETESB 2011), the values found classify the Paracatu area as being contaminated and with potential risks, direct or indirect, to human health, considered a scenario of wide exposure.

\subsection{Determination of As concentration in particulate matter (PM) of atmospheric air in the city of Paracatu-MG.}

The filters containing total suspended particles (TSP) from the atmosphere, coming from the samplers in the municipality of Paracatu were analyzed quantitatively for arsenic (As). The geographic location of the sampling stations is shown in Figure 1.

The results (Fig. 2C) show that the filters in the Mulberry region have the highest concentrations of As, demonstrating a greater risk for the population residing near the gold mine. It can also be observed that in the summer there is an increase in the amount of particulate matter in the city of Paracatu, as it is a period with the occurrence of higher temperatures and a higher incidence of gusty winds. It is important to note that wind gusts can occasionally increase the resuspension of soil particles and dust dispersion.

In rural areas the average concentrations of As are considered to range from 1 to $4 \mathrm{ng} \cdot \mathrm{m}^{3}$ while in urban areas, they range from 5 to $7 \mathrm{ng} \mathrm{m}^{3}$ (measurements carried out in the United Kingdom). In the United States, As concentrations are estimated to range from 1 to $5 \mathrm{ng} \mathrm{m}^{3}$ in remote/rural areas and from 20 to 
$100 \mathrm{ng} \mathrm{m}^{3}$ in urban areas (ATSDR 2019). However, in methodologies for assessing environmental risks to human health due to exposure to As in the atmosphere, via inhalation, for carcinogenic effects, the average reference levels of As concentration for acceptable risks range from $0.2 \mathrm{ng} \mathrm{m}^{3}$ to $0.6 \mathrm{ng} \mathrm{m}^{3}$ for risks of $1: 1.000 .000\left(10^{-6}\right)$ and $2 \mathrm{ng} \mathrm{m}^{3}$ to $6 \mathrm{ng} \mathrm{m}^{3}$ for risks of $1: 100.000\left(10^{-5}\right)$ (USEPA - United States Environmental Protection Agency 2011).

For non-carcinogenic effects, the California Environmental Protection Agency CalEPA, established as a reference maximum level of concentration of As in the atmosphere, by chronic inhalation, as being $30 \mathrm{ng}$ m3. This limit is a concentration below which toxic, non-carcinogenic effects are not expected to appear in the human population (Huang and London 2012).

Although all As values in the PM of this study are below the recommended limits, the accumulation generated by the intake of As present in water, food, and PM can reach high levels in the human organism, being a cause for concern. Mortality and cancer increase in regions where the atmospheric As is greater than $2 \mathrm{ng} \mathrm{m}^{3}$ (Yoshikawa et al. 2008).

\subsection{Quantification of As species $\left(\mathrm{As}^{3+}, \mathrm{As}^{5+}, \mathrm{MMA}\right.$ e DMA) in samples of corn, cassava and fish exposed to water and soil on the banks of the Rico stream.}

The Fig. 4 presents the results for speciation of arsenic in samples of fish (Traíra and Dourado), corn, and manioc. All samples showed a total value of As ( $\sum$ As) above the limits established by RDC 42 (ANVISA, 2013).

The samples of Traíra (fish) showed the highest concentrations of As, with a sum between the species of As of $2.794 \mathrm{mg} \mathrm{kg}^{-1}$, being above the maximum limit of $1.0 \mathrm{mg} \mathrm{kg}^{-1}$. The $\mathrm{As}^{3+}$ species was the most prevalent with $2.233 \mathrm{mg} \mathrm{kg}^{-1}$, followed by $\mathrm{As}^{5+}$ and DMA with 0.381 and $0.180 \mathrm{mg} \mathrm{kg}^{-1}$ respectively. The Traíra belongs to the family ERYTHRINIDAE, whose main characteristics are carnivorous and predatory fish, feeding on other fish, frogs, and insects, which preferably inhabit lentic environments and have nocturnal habits. They are located next to the mud bottom, in rocky or rocky locations, with high resistance to places with little oxygen (Soares et al. 2016). These characteristics explain the higher concentration of $\mathrm{As}^{3+}$, normally present in sediments and in places with little oxygen. Golden fish had a total As concentration of $2.64 \mathrm{mg} \mathrm{kg}^{-1}$, being also above the $1.0 \mathrm{mg} \mathrm{kg}^{-1}$ limit, Golden fish, on the other hand, had a total As concentration of $2.64 \mathrm{mg} \mathrm{kg}^{-1}$, which is also above the limit of $1.0 \mathrm{mg} \mathrm{kg}^{-1}$. It presents $2.63 \mathrm{mg} \mathrm{kg}^{-1}$ of DMA and $0.01 \mathrm{mg} \mathrm{kg}^{-1}$ of MMA. The Dourado is also a species of fish that is carnivorous, which feeds on smaller fish, but also consumes aquatic plants and is usually found in running waters.

The differences of fish species in the kinetic behavior (accumulation and elimination) of As were observed for other fish species, as well as a correlation between the fish family and the speciation patterns of As (Kalantzi et al. 2017). In a recent experiment, the accumulation of DMA in Goldfish was mainly attributed to biotransformation rather than trophic transfer. It has been reported that, within the 
fish organism, biotransformation and detoxification mechanisms, such as the reduction of inorganic arsenic, received through diet or water, followed by methylation to less toxic organic forms (Zhang et al. 2016). Inorganic arsenic is methylated via oxidative methylation, forming first MMA and then DMA. An alternative methylation scheme in which MMA and DMA are produced using a common $\mathrm{As}^{3+}{ }_{-}$ triglutathione complex has also been proposed. In both cases, the sequential formation of DMA can explain its positive correlation (Thomas 2007).

Regarding the results obtained in the cassava samples, total As values $\left(0.758 \mathrm{mg} \mathrm{kg}^{-1}\right)$ were also well above the legal limit of $0.1 \mathrm{mg} \mathrm{kg}^{-1}$. $\mathrm{As}^{5+}$ was the most prevalent, with $0.441 \mathrm{mg} \mathrm{kg}^{-1}$, followed by DMA and $\mathrm{As}^{3+}$ with 0.247 and $0.07 \mathrm{mg} \mathrm{kg}^{-1}$ respectively.

Corn also showed values above the $0.2 \mathrm{mg} \mathrm{kg}^{-1}$ limit, with $0.405 \mathrm{mg} \mathrm{kg}^{-1}$ of total As, which represents the sum of $\mathrm{As}^{5+}$, DMA, and MMA species with $0.31,0.075$, and $0.02 \mathrm{mg} \mathrm{kg}^{-1}$ respectively. When some plant species such as corn and cassava are grown in environments rich in As, it is common to experience a bioaccumulation process (Munera-Picazo et al. 2014). As ${ }^{5+}$ was shown to be the most bioavailable for both cassava and maize, which represents the greatest risk for human consumption, since the inorganic species of As are the most toxic and remain the longest in the body, as they carry out more connections with biological structures. Such results corroborate the high As values found in water and soil in this region (Fig. 2)

\subsection{Allium cepa test}

\subsubsection{Analysis of toxicity of Rico stream waters}

The seeds submerged in the different samples of the Rico stream showed a lower root growth rate than those obtained in the negative control. The results of the cytotoxicity test expressed in Table 2, demonstrate that the roots of Allium cepa are susceptible to toxic compounds present in the samples, causing an inhibition that prevents normal growth of the roots. The sites close to mining showed significant inhibition values as can be seen in points 1,2, and 3 . Although location 5 is the furthest from the mining area, it presented the highest rate of inhibition. This point also showed the highest concentration of As in soil and water samples.

As can interfere with root growth as a result of inhibition of the electron transport chain, replacing phosphate with arsenate, thus causing a reduction in energy production during cellular respiration. (Sharples et al. 2000; Kabata-Pendias 2010).

\subsubsection{Mitotic Index}

Mitotic index significantly lower than that of the negative control may represent changes originated from the action of chemical compounds on the growth and development of the exposed organisms and MI greater than the negative control as a result of the growth of cell division can be harmful to cells resulting in cell proliferation messy (Leme and Marin-morales 2009). All samples had an IM lower than the 
negative control (Table 3), proving the existence of toxic substances in the analyzed water. Studies have shown that the reduction in cell activity may be due to changes in the duration of the mitotic cycle (Kumari et al. 2009), which can contribute to cytotoxicity.

\subsubsection{Genotoxicity Analysis}

Chromosomal aberrations, evaluated for genotoxicity analysis, are characterized by changes in chromosomal structures or in the total number of chromosomes, considered at different stages of cell division, which can occur spontaneously or by exposure to contaminants. Genotoxicity studies were carried out by analyzing the chromosomal aberrations (CA) present in the slides prepared for this study. The changes considered for this study were chromosomal breaks, C-metaphase, losses, bridges, sticky chromosome, and spindle abnormalities (Fig. 5). Approximately 5000 cells were evaluated for each sample.

All samples analyzed showed an increase in chromosomal aberrations present in meristematic cells in cell division when compared to the negative control, indicating genotoxicity. As noted in Table 4, both points 1, 2, and 3 near the gold mine, as well as points 4 and 5 , more distant, presented significant chromosomal aberrations in relation to the control, which proves the As-genotoxic effect in stream waters Rich. The work of (Darlington and McLeish 1951; Kumari et al. 2009) suggested that the viscosity may be due to the degradation or depolymerization of chromosomal DNA. Viscosity was also attributed to the entanglement of interchromosomal chromatin fibers. Viscosity is a common sign of toxic influence on chromosomes and is probably an irreversible effect. It can represent a great risk for the human population, which consumes water with a high concentration of arsenic, with observed genotoxic effects.

\subsubsection{Mutagenicity Analysis}

The analysis of the mutagenic potential was performed based on the frequencies of meristematic cells with micronuclei. The micronucleus arises from the development of some chromosomal aberrations, such as chromosomal breaks and losses, by the development of a new membrane that involves a piece of chromatin that failed to pass to the poles during the anaphase of cell division. The analysis was performed for all phases of the cell cycle (interphase, prophase, metaphase, anaphase, and telophase); 5000 cells counted for each sample were studied and the results are shown in Fig. 6.

In this study, all samples showed a statistically greater amount of micronuclei in relation to the negative control $(p<0.05)$, indicating a mutagenic potential. This increase was significantly greater in samples that contained a greater amount of As, as observed in other studies. According to work by (Faita et al. 2013) exposure to As promoted an increase in DNA fragmentation rates and the frequency of micronuclei, in addition to a drop in $\mathrm{Ml}$, these responses being dependent on the concentration and time of exposure to the pollutant.

The genotoxic and mutagenic evaluation of effluents containing metals was observed in the work of (Matsumoto et al. 2006), where samples of waters from the Bagres Stream (Brazil), which receive 
effluents from tanneries caused significant induction of chromosomal aberrations and micronuclei. Studies carried out on the Sava River (Croatia), impacted by urban, industrial, and agricultural effluents, showed through the Allium cepa test the inhibition of root growth, variations in the mitotic index, high frequencies of chromosomal aberrations, and micronuclei in the cells analyzed (Bianchi et al. 2011).

\section{Conclusion}

This study demonstrated the usefulness of combining analytical methods in analyzes of soil, water, PM, and biological samples with cytogenetic methods to better understand the toxicity of chemicals and their risks to the environment, enabling more efficient environmental remediation.

Analyzes of Allium cepa demonstrate the cytotoxic, genotoxic, and mutagenic risk of elements present in the waters of the Rico stream.

The presence of As was found in water, soil, and particulate matter environments, influenced by seasonal variation, indicating environmental contamination that is aggravated by mining in the region. Moreover was an increase in As in areas with domestic effluent discharge, giving an indication of As in the organism of residents of the region. And, the presence of As in biologicals (fish, corn, and manioc) indicates the trophic transfer of this element, characterizing ecological damage, which affects species in this area and puts human health at risk.

\section{Declarations}

\section{Acknowledgments}

The authors are grateful to Federal University of the Jequitinhonha and Mucuri Valleys (UFVJM), National Council for Scientific and Technological Development (CNPq), Foundation for Research Support of the State of Minas Gerais (FAPEMIG), Network Mineira of Chemistry (RQ-MG), and Coordination of Improvement of Higher Level Personnel (CAPES) for the financial support and fellowships.

\section{References}

1. (ANVISA) AN de VS (2013) RDC $n^{\circ} 42$ de 29 de Agosto de 2013. Diário Of da União

2. APHA, AWWA W (2012) Standard Methods for Examination of Water and Wastewater, 22nd edn. American Public Health Association, Washington

3. ATSDR (2019) ATSDR's Substance Priority List. In: Agency Toxic Subst. Dis. Regist. https://www.atsdr.cdc.gov/spl/index.html

4. Barra CM, Santelli RE, Abrão JJ, Guardia M de la (2000) Especiação de Arsênio - uma revisão. Quim Nova 23:58-70. https://doi.org/10.1590/s0100-40422000000100012

5. Batista BL, de Oliveira Souza VC, da Silva FG, Barbosa F (2010) Survey of 13 trace elements of toxic and nutritional significance in rice from Brazil and exposure assessment. Food Addit Contam Part B 
Surveill 3:253-62. https://doi.org/10.1080/19393210.2010.516024

6. Bianchi J, Espindola ELG, Marin-Morales MA (2011) Genotoxicity and mutagenicity of water samples from the Monjolinho River (Brazil) after receiving untreated effluents. Ecotoxicol Environ Saf 74:82633. https://doi.org/10.1016/j.ecoenv.2010.11.006

7. Blanc LR, Moreira F dos S, Gonçalves AM, et al (2013) Contamination in a Brazilian River: A Risk of Exposure to Untreated Effluents. J Environ Qual 42:1596-1601. https://doi.org/10.2134/jeq2013.02.0068

8. Borba RP, Coscione AR, Figueiredo BR, Zambello F (2009) Estudo da especiação de arsênio inorgânico e determinação de arsênio total no monitoramento ambiental da qualidade de águas subterrâneas. Quim Nova 32:970-975. https://doi.org/10.1590/s0100-40422009000400027

9. Brasil (2018) INMET. In: Inst. Nac. Meteorol. Minist. da Agric. Pecu. e Abastecimento, MAPA

10. Brewer R, Belzer W (2001) Assessment of metal concentrations in atmospheric particles from Burnaby Lake, British Columbia, CAN. Atmos Environ. https://doi.org/10.1016/S13522310(01)00343-0

11. CETESB (2011) Guia Nacional de Coleta e Preservação de Amostras - Água, Sedimento, Comunidades Aquáticas e Efluentes Líquidos. Brasília-DF

12. CONAMA (2009) Resolução Nº 420, De 28 De Dezembro De 2009

13. Conama CN do MA (2005) RESOLUÇÃO CONAMA n. 357, de 17 de março de 2005 Publicada no DOU n. 357

14. CONAMA CNDMA (2004) Resolução CONAMA 344/2004. Diário Of da União

15. Darlington CD, McLeish J (1951) Action of maleic hydrazide on the cell. Nature 167:407-408. https://doi.org/10.1038/167407a0

16. De Andrade RP, De Mello JWV, Windmöller CC, et al (2012) Evaluation of arsenic availability in sulfidic materials from gold mining areas in Brazil. Water Air Soil Pollut 223:4679-4686. https://doi.org/10.1007/s11270-012-1224-3

17. De Andrade RP, Santana Filho S, De Mello JWV, et al (2008) Arsenic mobilization from sulfidic materials from gold mines in Minas Gerais State. Quim Nova 31:1127-1130. https://doi.org/10.1590/s0100-40422008000500037

18. Dos Santos Farias J, Milani MR, Niencheski LFH, De Paiva ML (2012) Especiação química De arsênio inorgânico no Estuário Da Laguna Dos Patos (RS, Brasil). Quim Nova 35:1401-1406. https://doi.org/10.1590/S0100-40422012000700021

19. Faita F, Cori L, Bianchi F, Andreassi MG (2013) Arsenic-induced genotoxicity and genetic susceptibility to arsenic-related pathologies. Int J Environ Res Public Health. https://doi.org/10.3390/ijerph10041527

20. Fiskesjö G (1985) The Allium test as a standard in environmental monitoring. Hereditas 102:99-112. https://doi.org/10.1111/j.1601-5223.1985.tb00471.x

21. Google (2020) Google Earth. Http://mapas.google.com 
22. Grant WF (1982) Chromosome aberration assays in allium. A report of the U.S. environmental protection agency gene-tox program. Mutat Res Genet Toxicol. https://doi.org/10.1016/01651110(82)90046-X

23. Hettick BE, Cañas-Carrell JE, French AD, Klein DM (2015) Arsenic: A Review of the Element's Toxicity, Plant Interactions, and Potential Methods of Remediation. J Agric Food Chem 63:7097-107. https://doi.org/10.1021/acs.jafc.5b02487

24. Hott RC, Magalhães TS, Maia LFO, et al (2020) Purification of arsenic-contaminated water using iron molybdate filters and monitoring of their genotoxic, mutagenic, and cytotoxic effects through bioassays. Environ Sci Pollut Res 28:5714-5730. https://doi.org/10.1007/s11356-020-10856-3

25. Huang G, London JK (2012) Cumulative environmental vulnerability and environmental justice in California's San Joaquin Valley. Int J Environ Res Public Health 9:1593-1608. https://doi.org/10.3390/ijerph9051593

26. IGAM (2019) Instituto Mineiro de Gestão das Águas. . Inf. N 4

27. Jang Y-C, Somanna Y, Kim H (2016) Source, Distribution, Toxicity and Remediation of Arsenic in the Environment - A review. Int J Appl Environ Sci ISSN

28. Jasrotia S, Kansal A, Kishore VVN (2013) Application of solar energy for water supply and sanitation in arsenic affected rural areas: A study for Kaudikasa village, India. J Clean Prod 37:389-393. https://doi.org/10.1016/j.jclepro.2012.10.034

29. Kabata-Pendias A (2010) Trace elements in soils and plants: Fourth edition. CRC Press

30. Kalantzi I, Mylona K, Sofoulaki K, et al (2017) Arsenic speciation in fish from Greek coastal areas. J Environ Sci (China) 56:300-312. https://doi.org/10.1016/j.jes.2017.03.033

31. Klaassen CD (2013) Casarett \& Doull's Toxicology: The Basic Science of Poisons, 9th edition

32. Kumari M, Mukherjee A, Chandrasekaran N (2009) Genotoxicity of silver nanoparticles in Allium cepa. Sci Total Environ 407:5243-6. https://doi.org/10.1016/j.scitotenv.2009.06.024

33. Leme DM, Marin-morales MA (2009) Allium cepa test in environmental monitoring: A review on its application. Mutat Res Mutat Res 62:71-81. https://doi.org/10.1016/j.mrrev.2009.06.002

34. Libânio M, Sperling E von, Bastos RKX, et al (2006) Vigilância E Controle Da Qualidade Da Água Para Consumo Humano. Brasília-DF

35. Mandal BK, Suzuki KT (2002) Arsenic round the world: A review. Talanta 58:201-35. https://doi.org/10.1016/S0039-9140(02)00268-0

36. Matsumoto ST, Mantovani MS, Malaguttii MIA, et al (2006) Genotoxicity and mutagenicity of water contaminated with tannery effluents as evaluated by the micronucleus test and comet assay using the fish Oreochromis niloticus and chromosome aberrations in onion root-tips. Genet Mol Biol 29:148-158. https://doi.org/10.1590/S1415-47572006000100028

37. Mertens F, Távora R, Nakano EY, Castilhos ZC (2017) Information sources, awareness and preventive health behaviors in a population at risk of Arsenic exposure: The role of gender and social networks. PLoS One 12:1-14. https://doi.org/10.1371/journal.pone.0186130 
38. Ministério da Saúde (2004) Portaria MS Nº 518/2004

39. Mourão AO, Silva DF, Rodriguez M, et al (2019) Degradation of haloacetic acids with the Fenton-like and analysis by GC-MS: use of bioassays for monitoring of genotoxic , mutagenic and cytotoxic effects. Env Monit Assess 191:513. https://doi.org/https://doi.org/10.1007/s10661-019-7642-6

40. Munera-Picazo S, Burló F, Carbonell-Barrachina ÁA (2014) Arsenic speciation in rice-based food for adults with celiac disease. Food Addit Contam - Part A Chem Anal Control Expo Risk Assess 31:1358-66. https://doi.org/10.1080/19440049.2014.933491

41. Ng JC, Ciminelli V, Gasparon M, Caldeira C (2019) Health risk apportionment of arsenic from multiple exposure pathways in Paracatu, a gold mining town in Brazil. Sci Total Environ 673:36-43. https://doi.org/10.1016/j.scitotenv.2019.04.048

42. Parron LM, Muniz DH de F, Pereira CM (2011) Manual de procedimentos de amostragem e análise físico-química de água

43. Pruszkowski E, Bosnak CP (2007) The Analysis of Drinking Waters by U . S . EPA Method 200 . 8 Using the NexION Standard, Collision and Reaction Modes

44. Rezende PS, Costa LM, Windmöller CC (2015) Arsenic Mobility in Sediments from Paracatu River Basin, MG, Brazil. Arch Environ Contam Toxicol 68:588-602. https://doi.org/10.1007/s00244-0150134-y

45. Rizzatti IM, Barbosa MT, Fernandes F da S, et al (2018) Avaliação de parâmetros físicos, químicos e microbiológios de água de alguns poços do bairro Jardim das copaíbas, Boa Vista, Roraima. Ambient Gestão e Desenvolv 11:17-32. https://doi.org/10.24979/65

46. Rocha BC, Almeida EA, Moreira AB, Bisinot MC (2015) Relações entre acúmulo de metais em tecido muscular de peixes com diferentes hábitos alimentares coletados na Bacia Hidrográfica do Turvo/Grande. Aleph 11:1-16. https://doi.org/10.17271/1980082711620151234

47. Sharples JM, Meharg AA, Chambers SM, Cairney JWG (2000) Mechanism of arsenate resistance in the ericoid mycorrhizal fungus Hymenoscyphus ericae. Plant Physiol 124:1327-34. https://doi.org/10.1104/pp.124.3.1327

48. Siciliano B, Dantas G, da Silva CM, Arbilla G (2020) The updated Brazilian national air quality standards: A critical review. J Braz Chem Soc 31:523-535. https://doi.org/10.21577/01035053.20190212

49. Silva SR, Procópio So, Queiroz TFN, Dias LE (2004) Caracterização de rejeito de mineração de ouro para avaliação de solubilização de metais pesados e arsênio e revegetação local. Rev Bras Ciência do Solo 28:189-196. https://doi.org/10.1590/s0100-06832004000100018

50. Soares JLF, Goch YGF, Peleja JRP, et al (2016) Bioacumulação de Mercúrio Total (HgT) e Hábitos Alimentares de Peixes da Bacia do Rio Negro, Amazônia, Brasil. Biota Amaz 6:102-106. https://doi.org/10.18561/2179-5746/biotaamazonia.v6n1p102-106

51. Souza JMO, Carneiro MFH, Paulelli ACC, et al (2015) Arsenic and rice: Toxicity, metabolism, and food safety | Arsênio e arroz: Toxicidade, metabolismo e segurança alimentar. Quim Nova 38:118-127. https://doi.org/10.5935/0100-4042.20140279 
52. States U, Protection E (1999) Compendium of Methods for the Determination of Toxic Organic Compounds in Ambient Air - Second Edition Compendium of Methods Determination of Toxic Organic Compounds in Ambient Air

53. Styblo M, Del Razo LM, Vega L, et al (2000) Comparative toxicity of trivalent and pentavalent inorganic and methylated arsenicals in rat and human cells. Arch Toxicol 74:289-99. https://doi.org/10.1007/s002040000134

54. Thomas DJ (2007) Molecular processes in cellular arsenic metabolism. Toxicol Appl Pharmacol 222:365-373. https://doi.org/10.1016/j.taap.2007.02.007

55. Thompson DJ (1993) A chemical hypothesis for arsenic methylation in mammals. Chem Biol Interact 88:89-14. https://doi.org/10.1016/0009-2797(93)90086-E

56. USEPA (2007) Method 3051A: Microwave assisted digestion of sediments, sludges, soils and oils. Test methods USEPA - United States Environmental Protection Agency (2011) Standard Test Method for Determination of Volatile Organic Chemicals in Atmospheres ( Canister Sampling Methodology ) 1

57. Wang M, Bera G, Mitra K, et al (2020) Tight sorption of arsenic, cadmium, mercury, and lead by edible activated carbon and acid-processed montmorillonite clay. Environ Sci Pollut Res 28:6758-6770. https://doi.org/10.1007/s11356-020-10973-z

58. Wang S, Mulligan CN (2006) Occurrence of arsenic contamination in Canada: Sources, behavior and distribution. Sci Total Environ 366:701-21. https://doi.org/10.1016/j.scitotenv.2005.09.005

59. WHO (2011) Guidelines for Drinking-water Quality 4th ed., WHO, Geneva, p. 340.

60. Yin H, Kong M, Gu X, Chen H (2017) Removal of arsenic from water by porous charred granulated attapulgite-supported hydrated iron oxide in bath and column modes. $\mathrm{J}$ Clean Prod 166:88-97. https://doi.org/10.1016/j.jclepro.2017.08.026

61. Yoshikawa M, Aoki K, Ebine N, et al (2008) Correlation between the arsenic concentrations in the air and the SMR of lung cancer. Environ Health Prev Med 13:207-218. https://doi.org/10.1007/s12199008-0032-2

62. Zhang W, Guo Z, Zhou Y, et al (2016) Comparative contribution of trophic transfer and biotransformation on arsenobetaine bioaccumulation in two marine fish. Aquat Toxicol 179:65-71. https://doi.org/10.1016/j.aquatox.2016.08.017

\section{Tables}

Table 1 Result of the physical-chemical parameters ( $\mathrm{pH}$, hardness and turbidity) in the surface waters of the Rico stream, in the five selected points. The collections were carried out during the winter of 2017 (dry season) and the summer of 2018 (rainy season). Reference value: $\mathrm{pH}$ (6-9), Turbidity <40 UNT and hardness (soft or soft: $<50 \mathrm{mg} . \mathrm{L} \mathrm{CaCO}{ }_{3}$; moderate: between $50 \mathrm{mg} . \mathrm{L}$ and $150 \mathrm{mg} . \mathrm{L} \mathrm{CaCO}$; hard: between $150 \mathrm{mg} . \mathrm{L}$ and $300 \mathrm{mg} . \mathrm{L}$ of $\mathrm{CaCO}_{3}$; and very hard:> $300 \mathrm{mg} \cdot \mathrm{L}$ of $\mathrm{CaCO} 3$ (potability limit $500 \mathrm{mg} . \mathrm{L} \mathrm{CaCO}{ }_{3}$ ) (Conama 2005; Libânio et al. 2006). 


\begin{tabular}{|c|c|c|c|c|c|c|}
\hline \multirow[t]{2}{*}{ Analysis } & References & \multicolumn{5}{|c|}{ Collection points } \\
\hline & & P1 & $\mathrm{P} 2$ & P3 & P4 & P5 \\
\hline pH Summer & \multirow[t]{2}{*}{$6.0-9.0$} & 6.0 & 6.5 & 6.9 & 7.0 & 7.0 \\
\hline pH Winter & & 6.4 & 6.8 & 7.1 & 7.1 & 7.1 \\
\hline $\mathrm{Ca}^{+2}$ and $\mathrm{Mg}^{+2}\left(\mathrm{mg} \mathrm{L}^{-1}\right)$ Summer & \multirow[t]{2}{*}{ - } & 94.0 & 88.0 & 29.0 & 40.0 & 47.0 \\
\hline $\mathrm{Ca}^{+2}$ and $\mathrm{Mg}^{+2}\left(\mathrm{mg} \mathrm{L}^{-1}\right)$ Winter & & 49.0 & 41.0 & 19.0 & 35.0 & 48.0 \\
\hline Turbidity (UNT) Summer & \multirow[t]{2}{*}{$<40$} & 1.7 & 0.87 & 2.1 & 1.0 & 3.0 \\
\hline Turbidity (UNT) Winter & & 3.5 & 8.3 & 1.6 & 0.71 & 2.1 \\
\hline
\end{tabular}

Table 2 Average growth $(\mathrm{cm})$ and rate of inhibition of Allium cepa roots grown in a water sample from the Rico stream, collected in winter of 2017, at the five points of the study. Ultrapure water $(18 \mathrm{M} \Omega \mathrm{cm})$ for negative control (NC). ALR (average length of growing seeds). Different letters indicate significantly different values between treatments $(p<0.05)$.

\begin{tabular}{|lllllll|}
\hline Samples & P1 & P2 & P3 & P4 & P5 & NC \\
\hline ALR (cm) & $0.25 \pm 0.3^{\mathrm{a}}$ & $0.27 \pm 0.2^{\mathrm{a}}$ & $0.18 \pm 0.2^{\mathrm{b}}$ & $0.37 \pm 0.2^{\mathrm{c}}$ & $0.12 \pm 0.1^{\mathrm{d}}$ & $0.42 \pm 0.2^{\mathrm{e}}$ \\
\hline Inhibition rate & $41.00 \%$ & $37.00 \%$ & $55.30 \%$ & $11.31 \%$ & $66.22 \%$ & - \\
\hline
\end{tabular}

Table 3 Total mean mitotic indices (MI) obtained from meristematic cells (in mitosis) of Allium cepa root, cultivated with water from the Rico stream, collected in winter of 2017, at the five points of the study. Ultrapure water $(18 \mathrm{M} \Omega \mathrm{cm})$ for negative control (NC). Mitotic indices of 5.000 cells per group. Different letters indicate significantly different values between treatments $(p<0,05)$.

\begin{tabular}{|lllllll|}
\hline Samples & P1 & P2 & P3 & P4 & P5 & NC \\
\hline IM & $2,66 \%^{a}$ & $2,03 \%^{\mathrm{b}}$ & $1,75 \%^{\mathrm{c}}$ & $1,93 \%^{\mathrm{c}}$ & $2,20 \%^{\mathrm{b}}$ & $5,96 \%^{\mathrm{d}}$ \\
\hline
\end{tabular}

Tabela 4- Chromosomal aberrations (CA). Ultrapure water for negative control (NC). The number of cells analyzed (NCA). Different letters indicate significantly different values between treatments $(p<0,05)$. 


\begin{tabular}{|lllllllll|}
\hline Samples & NCA & Bridges & Losses & Breaks & $\begin{array}{l}\text { Sticky } \\
\text { chromosome }\end{array}$ & $\begin{array}{l}\text { C- } \\
\text { metaphase }\end{array}$ & $\begin{array}{l}\text { Spindle } \\
\text { anomalies }\end{array}$ & CA \\
\hline NC & 5000 & 2 & 2 & 19 & 0 & 4 & 0 & $27^{\mathrm{a}}$ \\
\hline Water P1 & 5000 & 9 & 3 & 28 & 20 & 24 & 2 & $86^{\mathrm{b}}$ \\
\hline Water P2 & 5000 & 7 & 1 & 22 & 20 & 17 & 1 & $68^{\mathrm{c}}$ \\
\hline Water P3 & 5000 & 5 & 0 & 17 & 18 & 12 & 0 & $52^{\mathrm{d}}$ \\
\hline Water P4 & 5000 & 4 & 3 & 16 & 5 & 12 & 0 & $40^{\mathrm{e}}$ \\
\hline Water P5 & 5000 & 7 & 4 & 23 & 22 & 21 & 3 & $80^{\mathrm{b}}$ \\
\hline
\end{tabular}

Figures

\section{Image not available with this version}

Figure 1

Map of the city of Paracatu-MG with the points of collection of water and soil samples. Adapted Google Earth (Google 2020), software ArcGis versão 10.8. 


\section{Image not available with this version}

\section{Figure 2}

Result of the analysis of arsenic in water (A) and soil (B) at the points (P1, P2, P3, P4, and P5) of the Rico stream; and atmosphere (C). Particulate matter up to $2.5 \mu \mathrm{m}$ (PM 2.5) and particulate matter in total suspension (PTS), collected in the regions of Amoreiras (AM), Chapadinha (CH), and Paracatu (PA). Analyzes were carried out in the winter of 2017 and summer of 2018. As limit (LM) $<10 \mu \mathrm{g}-1$ for surface water (Ministério da Saúde 2004; Conama 2005); < 15 mg kg-1 for soil (CONAMA 2004); > 35 mg $\mathrm{kg}-1$ requires agricultural intervention (CONAMA 2009)). $\mathrm{a}<0.05$.

\section{Image not available with this version}

\section{Figure 3}

Average rainfall index $(\mathrm{mm})$, and average maximum and minimum temperatures $\left(\mathrm{C}^{\circ}\right)$ over the months, from 1973 to 2018. measures obtained by the National Institute of Meteorology (Brasil 2018). 


\section{Image not available with this version}

\section{Figure 4}

Quantification of As species (As3+, As5+, MMA e DMA) in samples of corn, cassava, and fish exposed to water and soil on the banks of the Rico stream. $\sum A s$ s sum of As species; $L M=$ maximum limit of As (LM fish 1.0 mg kg-1, LM corn 0.2 mg kg-1, LM cassava 0.1 mg kg-1) (ANVISA, 2013).

\section{Image not available with this version}

Figure 5

Microscopic image of the subphases of mitosis of meristematic cells from the root of Allium cepa: (a) interphase, (b) prophases, (c) metaphase, (d) anaphase, (e) telophase and chromosomal aberrations (AC), (f) micronucleus interphase, (g) micronucleus prophase, (h) C- metaphase, (i) anaphase with chromosomal loss, (j) Telophase with bridge and break. 


\section{Image not available with this version}

Figure 6

The occurrence of micronuclei in Allium cepa meristematic cells exposed for $24 \mathrm{~h}$ to samples collected in the Rico stream (P1, P2, P3, P4, and P5) and negative control of ultrapure water (NC). Tukey test with significance level $q=0.05$. 